\title{
Ecotourism Development Strategy of Bukit Jaddih Karst, Madura
}

\author{
Rita Parmawati ${ }^{1 *}$, Rif'atul Imaniyah², Lutvita Eka Rokani², M. Iqbal Rajaguni², \\ Agung S. Kurnianto ${ }^{3}$ \\ ${ }^{1}$ Postgraduate School, Unversity ofBrawijaya, Malang, Indonesia \\ ${ }^{2}$ Master Program of Environmental and Development Studies, Unversity of Brawijaya, Malang, Indonesia \\ ${ }^{3}$ Laboratory of Ecology and Animal Diversity, Departement of Biology, Unversity of Brawijaya, Malang, Indonesia
}

\begin{abstract}
Bukit Jaddih karst in Bangkalan, Madura, is an ex-limestone mining location managed partially by individuals or community groups as tourism area. This study aims to develop sustainable strategies for Bukit Jaddih karst resources and ecotourism. Data were obtained from questionnaires given to 30 respondents consisting of visitors, miners, traders, society, and policymaker then being analyzed for the strategy on the development of tourism object. SWOT strategy was used to determine every aspect of tourism development (weight 0.00 to 1.00). Score are given in a rating where the rating indicates the level of importance. The IFAS analysis shows Bukit Jaddih karst has some dominant internal strengths, i.e. uniqueness, safety, cleanliness, access to food-stalls, and cellular networks covering tourist areas. However, tourist services in Bukit Jaddih karst are not good enough and indicated as dominant weakness. EFAS shows that Bukit Jaddih karst can provide employment opportunities for the surrounding community. The strategy of the Matrix analysis supports an aggressive growth policy (Growth Oriented Strategy), which is using the Strength Opportunities (SO) strategy and is applied based on the utilization of the opportunities of Bukit Jaddih karst ecotourism. The strategies to be developed are 1). Promotion through prints, TV, radio and social media; 2). Developing diversified tourism attractions; 3). Mapping the tourism potential of Bangkalan Regency; 4). Establishment of Tourism Awareness Group (Kelompok Sadar Wisata, Pokdarwis); 5). Training for local community as guide; 6). The establishment of Surabaya-Madura tourism package; 7). Establishment of regulations on the cleanliness, security, and comfort.
\end{abstract}

Keywords: Bukit Jaddih karst, EFAS, IFAS, strategy, tourism development.

\section{INTRODUCTION*}

Karst is topographically formed from a mixture of dissolved rocks, such as lime, dolomite, and gypsum, characterized by an underground river system of water in the soil with holes and caves [1,2]. Karst is very important as a source of clean water in the area, especially on the dry season [3]. Karst and cave are very valuable natural resources, becoming the habitat of a wide variety of ecological niche. In addition, many types of plants and animals, including endemic species, are found in the karst area. Karst also becomes a unique microbial habitat [4]. However, karst areas are threatened by human activities, mainly by farming and agricultural practices, fire, mining, urbanization, housing and infrastructure development, drilling and piping, material transport, and vegetation removal $[5,6]$.

The management of Karst as a tourism area has long been started in several countries. The Anina Karst complex, which is a former mine in Romania, has turned into an exploratory tour

\footnotetext{
${ }^{*}$ Correspondence address:

Rita Parmawati

Email : rita_parmawati@ub.ac.id

Address : Postgraduate School, University of Brawijaya, Jl. MT Haryono No. 169, Malang, 65145
}

that supports the socio-economic progress of the surrounding community [7]. In addition, the Kabar area of Puerto Rico is being developed into an ecotourism that promotes social, economic, and educational growth on the importance of karst in human life [8].

Bukit Jaddih karst in Bangkalan, Madura, is a former limestone area included in the Jaddih Karst area. Bukit Jaddih is one of the ancient karst formation in Indonesia, apart from other Karst Areas, such as Mount Lawu which consists of Gunung Kidul (Jogja), Wonogiri, Pacitan $[9,10]$, and Maros, South Sulawesi [11]. Unfortunately, with a variety of ancient geomorphic shapes, Bukit Jaddih karst is minimally protected as a nature reserve area. There is no protection against mining activities, and threatens the role of Bukit Jaddih karst as a conservation support of the area and the source of clean water.

Tourism is the best option for avoiding conflicts of interest, preserving the natural environment, and at the same time enhancing the social and economic values of society $[12,13,14]$. Therefore, recent mining activities have shifted to tourism. However, this new activity faces many challenges, such as the lack of structured management, the impact of mass tourism, and human activity on the sustainability of Karst's tourism and environment. This study 
aims to develop a sustainable strategy for Bukit Jaddih karst resources and ecotourism.

\section{RESEARCH METHOD}

\section{Study Site}

The research area is located in Socah Subdistrict, Bangkalan Regency, Madura, East Java. This karst area is a former limestone mining area that has been transformed into various tourist objects since 2014, such as Gua Pote spring, bathing place, Biru Lake, Jaddih Cave, and Jaddih hill (Fig. 1). In addition, there are a lot of resorts and shops opening in small groups of people.

\section{Data Collection}

Data were obtained from questionnaires given to 30 respondents consisting of visitors, miners, traders, society, and policy maker. The study was conducted on October 2017. Observations are also based on visible physical conditions and existing activities. The questionnaire is used as a representation of perceptions on Bukit Jaddih karst tourism, i.e. 1) strength (uniqueness, security, cleanliness, road conditions, distance, accommodation access, and cellular network), 2) weakness (noise, service, lack of accommodation and information), 3) Opportunities (potential employment, national tourism development, the rare of karst destination, Bukit Jaddih karst strategic positions, interesting sights on access roads), 4) threats (regulation, partial management, lack of investor, lack of tourism impact analysis, and unintegrated tariff).

\section{Analysis}

The results of the observations were analyzed descriptively. Then being analyzed for the strategy on the development of tourism object. Strategy development using SWOT analysis [12]. Some aspects of SWOT include aspects of strength (S), weakness (W), opportunity (O) and threat $(T)$, where all four are related to each other. Through these links, there will be some basic development strategies or concepts that can be used in ecotourism development of Bukit Jaddih karst, Bangkalan Madura both physical and non-physical. The determination of the basic concept of development is based on the SWOT analysis by assessing (weighting) using IFAS analysis (Internal Factor Analysis Summary)-EFAS (External Factor Analysis Summary) [12]. IFASEFAS was used for determining the regional development strategy, and then the assessment (weighting) which is presented in the form of quadrant will determine the next development strategy.

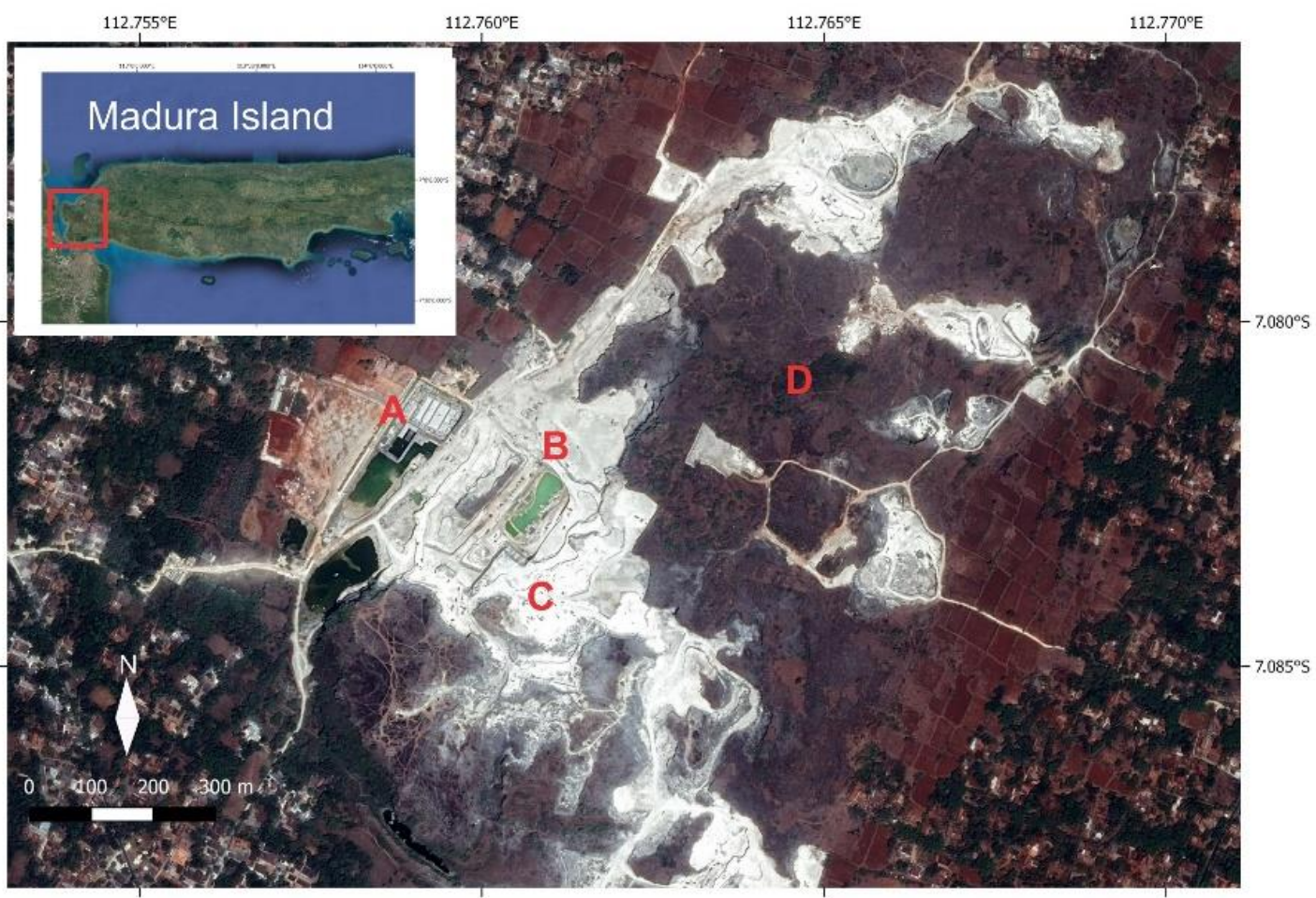

Figure 1. Bukit Jaddih karst: A.Bathing Place, B. Gua Pote Spring, C. Jaddih Hill, D. Jaddih Cave Source: GIS Analysis 2018 
Assessment is done on every aspect of the SWOT by assigning a weight 0.00 to 1.00 , which if the respective factors (internal/external) aspects is added, will get the weights 1 . After weighting, score are given in a rating where the rating indicates the level of importance (1= unimportant; 2=rather important; 3=important; $4=$ very important) of each aspect [12]. Then, the weighted value is multiplied by a determined rating. The sum of each factor (internal/external) is then being summed to create the SWOT quadrant in determining the development strategy.

\section{RESULT AND DISCUSSION}

Bukit Jaddih karst provides some observational tourism activities. The mining damage on Bukit Jaddih karst has been covered by beautiful, artificial and natural forms of fragments. The ex-sawmills form flat surface cliff, while digging process leave some artificial caves that are used for stalls (Fig.2).

Visitors do selfie to take their picture with a unique karst background. The color of white karst seemed to glow with the sunlight. Each
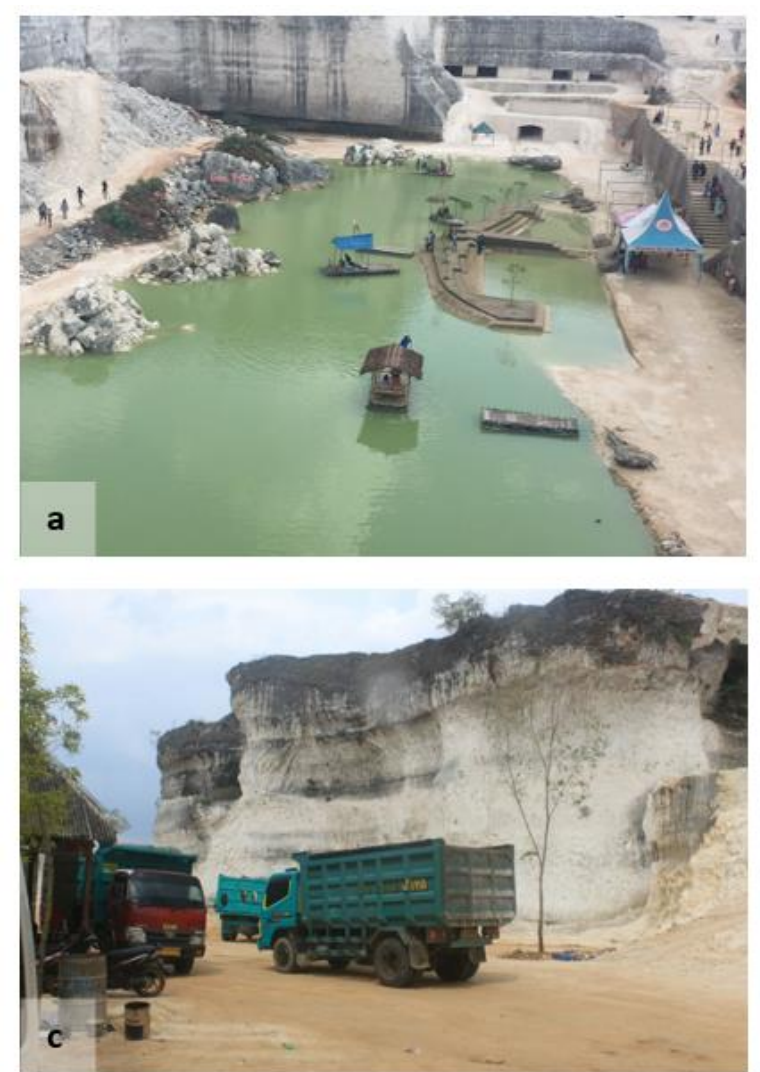

spot has a creative name board and colorful background.

There are some raftsfor exploring Gua Pote spring. Visitors can enjoy the view from the raft by paying IDR 5000, - (about USD 0.36) for each trip. It takes about 2 hours to explore all of Bukit Jaddih karst area.

The IFAS analysis shows Bukit Jaddih karst has some dominant weight (0.09) which consisted of uniqueness, safety, cleanliness, food access to food-stalls, and cellular networks covering tourism areas. However, tourist services in Bukit Jaddih karst is not good enough. This is illustrated by its weight dominance of 0.10 (Table 1). Less integrated service in Bukit Jaddih karst is the main cause of this fact.

The result of EFAS analysis shows that Bukit Jaddih karst can provide employment opportunities for the surrounding community, which is indicated by the factor weights that dominate among other factors (0.12). The public revealed that the opening of Bukit Jaddih karst as tourism area promised better economic income. However, the absence of regulations supporting tourism activities poses the highest threat in Bukit Jaddih karst (0.11) as mentioned in Table 2.
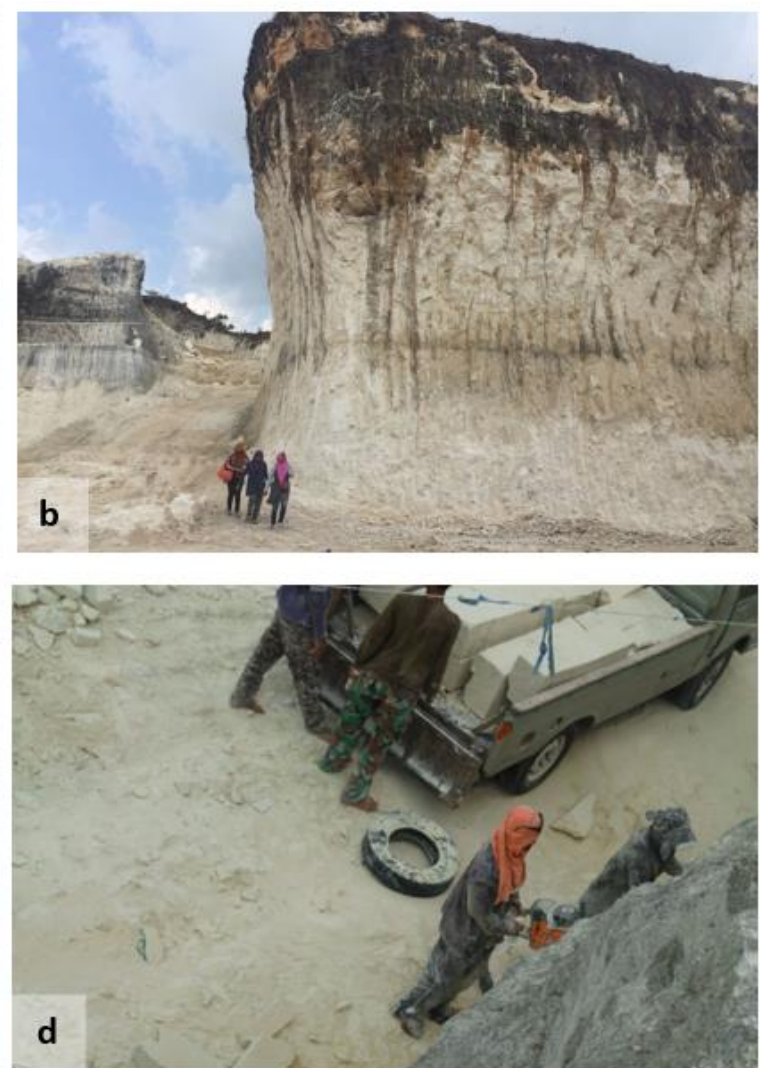

Figure 2. Bukit Jaddih karst and human activities. A. Tourism rafts at Gua Pote spring, B. Karst cliff as tourist photos background, $\mathrm{C}$. Trucks move limestone as cement raw material, D. Miners sawing limestone 
Table 1. Result of Assessment and Weighting of IFAS of Bukit Jaddih karst

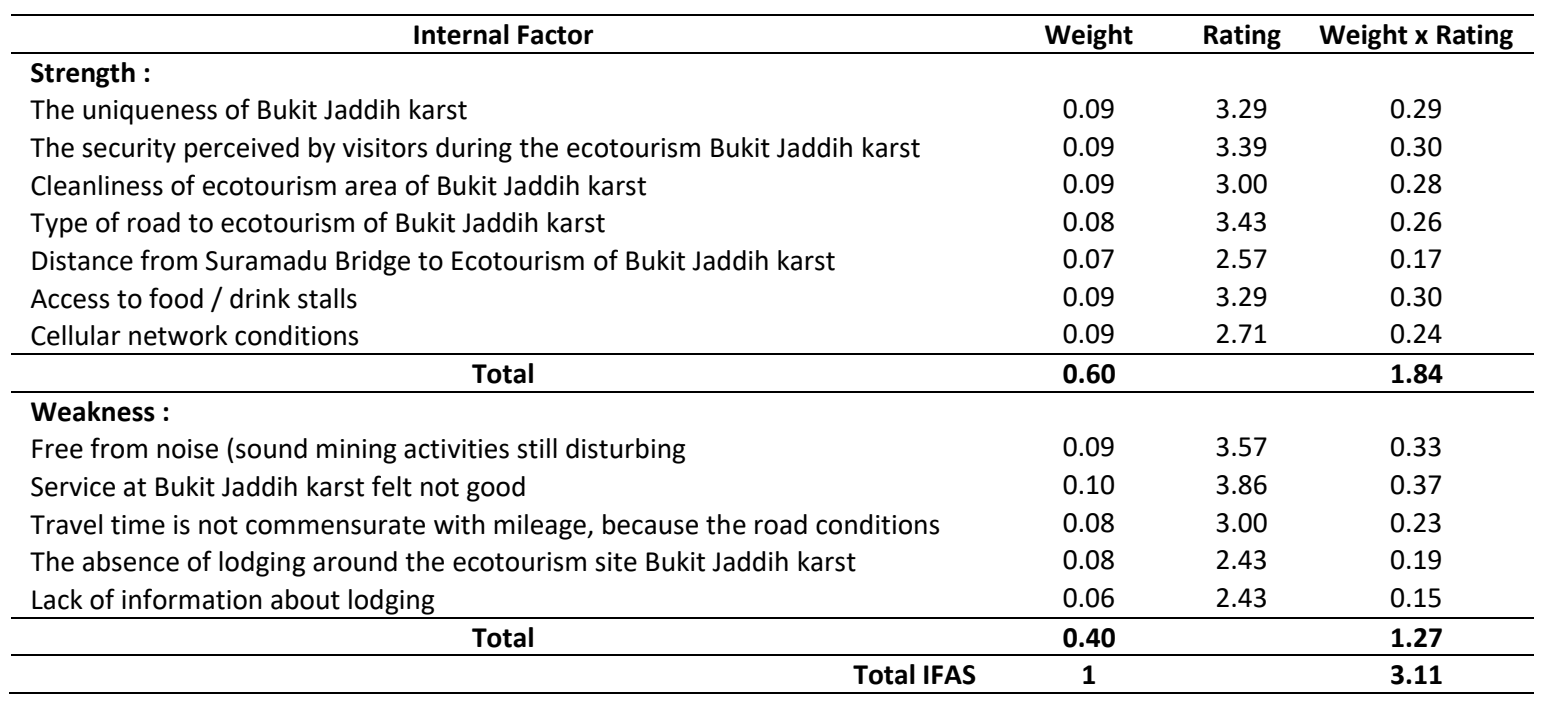

Table 2. Result of Assessment and Weighting of EFAS of Bukit Jaddih karst

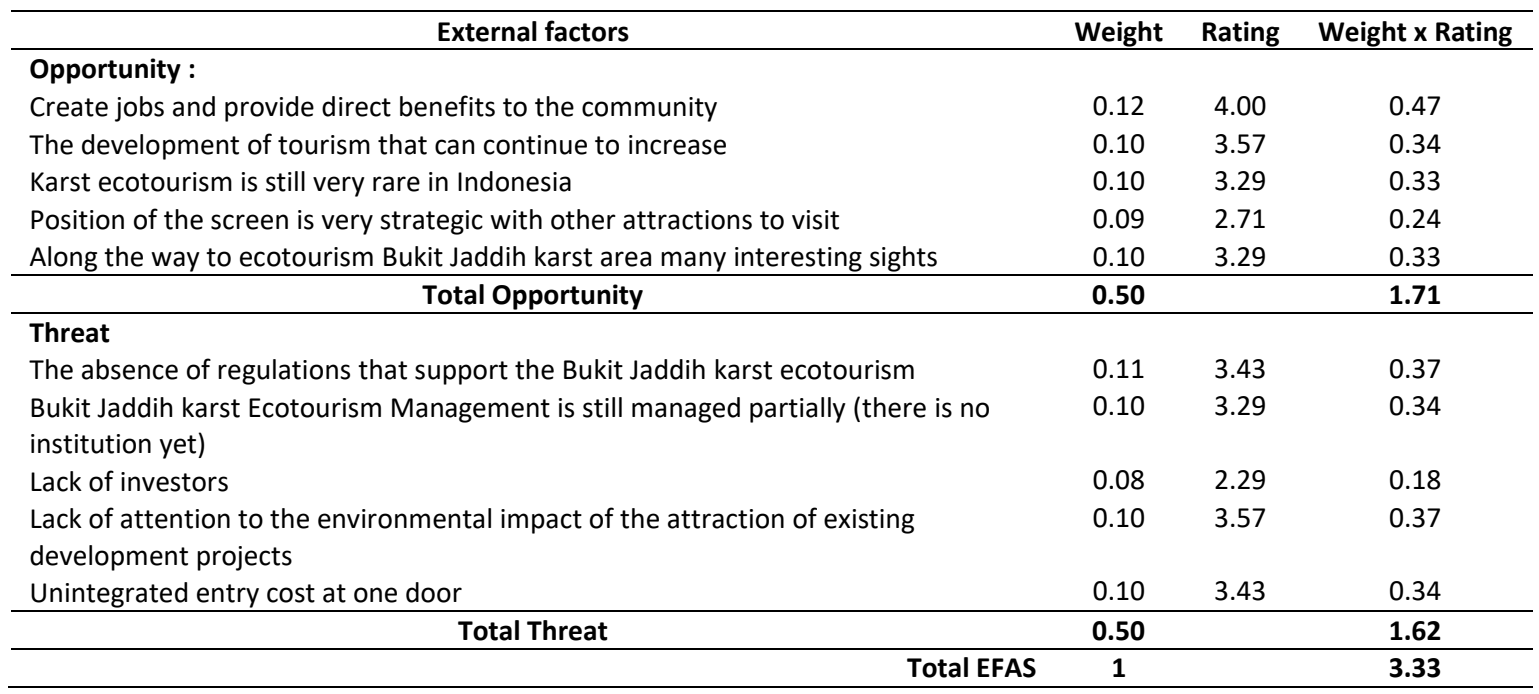

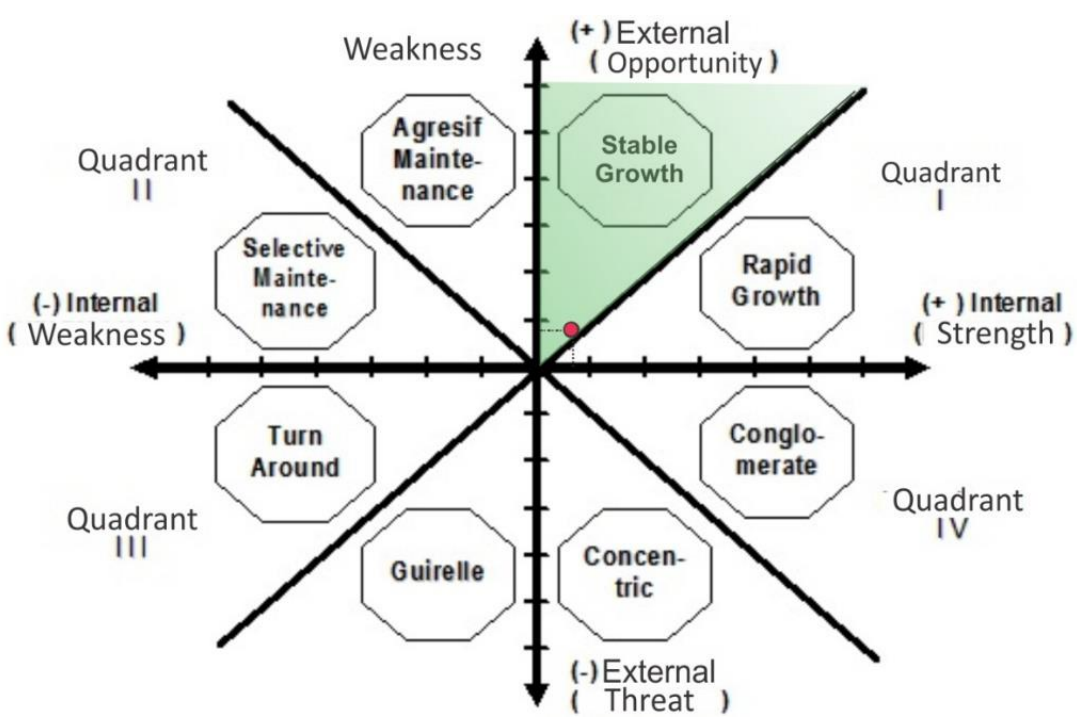

Figure 3.Bukit Jaddih karst development position on IFAS - EFAS Analysis Strategy Quadrant. The development position of Bukit Jaddih karst indicated by red point and green highlight. 
Based on the calculations with IFAS and EFAS, we can determine the value of $X$ and $Y . X$ is the value of the difference between Strength (1.84) and Weakness (1.27), i.e. 0.57 . $Y$ represents the difference between Opportunity (1.71) and Threat (1.62), i.e. 0.09. Then, we determined the position of Bukit Jaddih karst's tourism in the IFAS-EFAS strategy quadrant (Fig.3).

Based on the IFAS-EFAS strategy quadrant, the development of Bukit Jaddih karst is located in quadrant I of space B. Thus the strategy used in ecotourism development is the stable growth strategy; the development strategy of the object, which is in a huge opportunity situation to be developed according to the strengths.

The uniqueness of Bukit Jaddih karst is perceived by respondents as the main attraction that bring tourists to visit. Natural charms such as the unique landscape on Bukit Jaddih karst, become the driving motivation for nature-based tourism $[13,14]$. In addition, security, cleanliness, the existence of food and beverage shops in the tourism area into internal strength owned by Bukit Jaddih karst. These three factors arise due to the desire and participation of the community in managing the Bukit Jaddih karst tourism sector partially. Therefore, security, cleanliness, and access to the consumption of tourists need to be guaranteed. Safety and hygiene are supporting the establishment of sustainable tourism $[15,16]$. Its location where is not too far from other public center indicated by existence of cellular network which can be easily accessed by tourists at Bukit Jaddih karst. Several tourism areas along with various information and promotion facilities that are managed organically or privately, require fast and growing mobile network access $[16,17]$.

The existence of the desire groups and individuals who provide a tourism service, tend to impact on poor competition and weaken the object of tourism [14].One of the impact is the transition or multi-profession that they run, ranging from parking service providers, area service providers, sales of local merchandise, food and beverages that are managed individually or in small groups. The opening of tourism sites has always been a source of business and trade development potential. This activity is a response to the opportunities that appeared [18].

Regulation becomes the basis of a tourism site to continue to grow and is a very big support from the government. Regulation can be a limitation of tourism development to remain in the principles of sustainability, avoid unhealthy competition, become a means of educating people and tourists, and become a pathway for sustainable tourism development [19].

The strategy used is to minimize internal problems to bring up some of the great opportunities [20]. The strategy of the Matrix analysis supports an aggressive growth policy (Growth Oriented Strategy), which is using the Strength Opportunities (SO) strategy and is applied based on the utilization of the opportunities of Bukit Jaddih karst ecotourism. The compiled strategies are a representation of the wish that Bukit Jaddih karst be a form of sustainable ecotourism supported by community empowerment, environmental sustainability, and economic welfare.

Based on quadrant analysis, the development strategy can be arranged in a SWOT (Strength, Weakness, Opportunities and Threats) matrix. The strategies developed are: (1) Promotion through prints, TV, radio and social media to expand market share and increase the number of visits, (2) Developing diversified tourism attraction, (3) Mapping of tourism potential in Bangkalan Regency for the development of other types of tourism, (4) Establishment of Tourism Awareness Group (Pokdarwis) to assist the management of trade activity in Bukit Jaddih karst tourism area, (5) Training for local community as guide, so it is expected to increase income, (6) The establishment of SurabayaMadura tourism package, covering several Bangkalan tourism destinations that are professionally packed, (7) Establishment of regulations that regulate the cleanliness, security, and comfort of tourists.

Information media became one of the main supporting pillars of the establishment of sustainable tourism. Advances in information, such as the internet and mobile phone networks can make it easier for travelers to visit and receive accommodation services directly [17]. Diversification of attraction allows visitors to be more satisfied and experience a unique, educated, and well organized tourism atmosphere [14]. In addition, Bukit Jaddih karst should be supported by the strengthening of human resources, where in a sustainable ecotourism, local communities are expected to be heavily involved. External factor support strategy, in this case local government, is expected to be regulation, training, and mentoring. The government's attention will accelerate ecotourism development and maximize the role of local communities $[19,21]$. 


\section{CONCLUSION}

Based on the IFAS-EFAS strategy quadrant, the development of Bukit Jaddih karst is located in quadrant I of space B, so that the strategy used in ecotourism development is the stable growth strategy, or the development strategy of the object which is in a very big opportunity situation to be developed according to the strengths. The strategies developed are: (1) Promotion through prints, TV, radio and social media to expand market share and increase the number of visits, (2) Developing diversified tourist attraction, (3) Mapping of tourism potential of Bangkalan Regency for the development of other types of tourism, (4) Establishment of Tourism Awareness Group (Pokdarwis) to assist the management of trade activity in Bukit Jaddih karst tourism area, (5) Training for local community as guide, so it is expected to increase income, (6) Establishment of Surabaya-Madura tourism package, covering several Bangkalan tourism destinations that are professionally packed, (7) Establishment of regulations that regulate the cleanliness, security, and comfort of tourists.

\section{ACKNOWLEDGEMENT}

Authors thank Bangkalan District governmet for research permission and accommodation supports.

\section{REFERENCES}

[1] Fort, D.C. and P.W. Williams. 1999. Karst geomorphology and hydrology. Chapman and Hall.London.

[2] Galdenzi, S., M. Cocchioni, L. Morichetti, V. Amici and S. Scuri. 2008. Sulfidic ground water chemistry in the Frasassi Cave, Italy. Journal of Cave and Karst Studies 70, 94107.

[3] Fiorillo, F., P. Revellino and G. Ventafridda. 2012. Karst aquifer draining during dry periods. Journal of Cave and Karst Studies74, 148-156.

[4] Pipan, T. and D.C. Culver. 2013. Forty years of epikarst: what biology have we learned? International Journal of Speleology 42, 215223.

[5] Langer, W.H. 2001. Potential environmental impacts of quarrying stone in karst a literature review. Open-file report OF-010484.US Geological Survey.

[6] diMaggio, C., G. Madonia, M. Parise and M. Vattano. 2012. Karst of Sicily and its conservation. Journal of Cave and Karst Studies74,157-172.
[7] Artugyan, L. 2014. Geomorphosites as a valuable resource for tourism development in a deprived area: the case study of Anina Karsatic Region (Banat Mountains), Romania. Analele Universităţii din Oradea, SeriaGeografie2, 89-100.

[8] Hall, A. and M. Day. 2014. Ecotourism in the state forest karst of Puerto Rico. Journal of cave and Karst studies76, 30-41.

[9] Retnowati, A. 2014. Culture and risk based water and land management in karst area: An understanding of local knowledge in Gunungkidul, Java, Indonesia. Master Thesis. Program Study of Geography, Mathematic and Computer Science Faculty, University of Giessen. Hesse, Germany.

[10] Kusumayudha, S. B., J. Setiawan, A. N. Ciptahening and P. D. Septiana. 2015. Geomorphologic model of Gunungsewu karst, Gunung Kidul Regency, Yogyakarta Special Territory, Indonesia: The role of lithologic variation and geologic structure. Journal of Geological Resource and Engineering 1, 1-7.

[11] Arsyad, M., H. Pawitan, P. Sidauruk and E. I. K. Sari. 2014. Analisis ketersediaan air sungai bawah tanah dan pemanfaatan berkelanjutan di kawasan Karst Maros Sulawesi Selatan. Jurnal Manusia dan Lingkungan 21(1), 8-14.

[12] Kent, M. 2003. Ecotourism, environmental preservation and conflicts over natural resources. Horizontes Antropológicos9(20), 185-203.

[13] Mensah, I. and A. Ernest. 2013. Community participation in ecotourism: the case of Bobiri Forest Reserve and butterfly sanctuary in Ashanti Region of Ghana. American Journal of Tourism Management 2(1A), 34-42.

[14] Blaj, R. 2014. Ecotourism and nature tourism - components of a sustainable management of forests. Journal of Horticulture, Forestry, and Biotechnology 18(4), 51-54.

[15] Ommani, A. R. 2011. Strengths, weaknesses, opportunities, and threats (SWOT) analysis for farming sytem businesses management: case of wheat farmers of Shadervan District, Shoushtar Township, Iran. African Journal of Business Management 5(22), 9448-9454.

[16] Faida, L. R. W. 2014. Primeval forest in the period of human cultural history on Gunungsewu Karst Indonesia. Journal of 
Procedia Environmental Sciences20, 795802.

[17] Jensen, O., Y. Li and M. Uysal. 2017. Visitors' satisfaction at managed tourist attractions in Northern Norway: Do on-site factors matter? Journal of Tourism Management63, 277-286.

[18] Amedie, F. A. 2013. Impacts of climate change on plant growth, ecosystem services, biodiversity, and potential adaptation measures.MasterThesis. Program Study of Biological and Enviromental Science, University of Gothenberg, Sweden.

[19] Parmawati, R., A. S. Leksono, B. Yanuwiadi and A.S. Kurnianto. 2017. Exploration of marine tourism in Watulimo, Trenggalek Regency: challenges, potentials, and development strategies. Journal of Indonesia Tourism and Development Studies 5(3), 175-184.

[20] Stange, J., Brown, D. and S. International. 2007. Tourism destination management: achieving sustainable and competitive results: Online tool kit and resource series, USAID. Available at: www.usaid.gov.

[21] Kiper, T., G. Ozdemir and C. Sağlam. 2011. Environmental, socio-cultural and economical effects of ecotourism perceived by the local people in the northwestern Turkey: Kiyiköy case. Scientific research and Essays 6, 4009-4020. 